\title{
Entanglement of CCR5 and Alzheimer's Disease
}

\author{
Tianwen $\mathrm{Li}^{1,2,3}$ and Jianhong Zhu ${ }^{1,2,4 *}$ \\ ${ }^{1}$ Department of Neurosurgery, Huashan Hospital, Fudan University, Shanghai, China, ${ }^{2}$ State Key Laboratory of Medical \\ Neurobiology, Shanghai, China, ${ }^{3}$ Shanghai Medical College, Fudan University, Shanghai, China, ${ }^{4}$ Institutes of Brain Science, \\ Shanghai, China
}

Although the mechanisms of Alzheimer's disease are diverse and unclear, the past 20 years have witnessed the unprecedented development of the $A D$ inflammation theory. As a key inflammatory receptor family, the C-C chemokine receptor family is a remarkable participant in the cause of Alzheimer's disease; of this family, CCR5 is the most widely studied. CCR5 is an essential entrance when HIV infects immune cells and is also involved in other inflammatory and immune activities. New evidence on the inevitably intertwined link between Alzheimer's disease and CCR5 indicates that CCR5 accelerates the development of Alzheimer's disease, and few studies disputed it. The role of CCR5 in Alzheimer's disease remains elusive. However, as the research progresses, this intricate relationship will gradually be uncovered.

Keywords: CCR5, Alzheimer's disease, neuroinflammation, microglia, neurodegeneration

\section{OPEN ACCESS}

Edited by:

Panteleimon Giannakopoulos, Université de Genève, Switzerland

Reviewed by:

Sergey Bachurin,

Institute of Physiologically Active Compounds (RAS), Russia

Boon-Seng Wong,

Singapore Institute of Technology,

Singapore

*Correspondence:

Jianhong Zhu

jzhu@fudan.edu.cn

Received: 02 June 2019

Accepted: 24 July 2019

Published: 07 August 2019

Citation:

Li T and Zhu J (2019)

Entanglement of CCR5

and Alzheimer's Disease.

Front. Aging Neurosci. 11:209.

doi: 10.3389/fnagi.2019.00209

\section{INTRODUCTION}

$\mathrm{C}-\mathrm{C}$ chemokine receptors 5 (CCR5) is a kind of cytokine belonging to the $\beta$ chemokine receptor family of integral membrane proteins (Power et al., 1995). CCR5 is well known (or notorious) mainly because it collaborates with human immunodeficiency virus-1 (HIV-1) when the virus enters target immunological cells (Murphy, 2001; Ghalib, 2009). Intriguingly, most current antiHIV drugs target CCR5. At the end of the 2018, the announcement of Chinese gene edited infants whose CCR5 genes were deleted by CRISPR-Cas9 again brought the debate about CCR5 to the forefront.

Alzheimer's disease (AD), characterized by typical pathological changes such as senile plaques and neurofibrillary tangles, is the most prevalent neurodegenerative disorder. With the aging of the population, the battle with $\mathrm{AD}$ will become more difficult. Although the causes and pathogenetic mechanisms remain uncertain, there is growing evidence linking neuroinflammation with $A D$ (Khoury, 2010; Heneka et al., 2015). Numerous cytokines, e.g., tumor necrosis factor (TNF) (Irene et al., 2015), interleukin-1 (IL-1) (Irene et al., 2015), interleukin-6 (IL-6) (Haddick et al., 2017), and colony-stimulating factor (CSF) (Vincent et al., 2009), have been suggested to be connected with the course of AD. Additionally, many variants in immune genes such as TREM2, CD33 and CR1 were recognized by genome-wide association studies (GWAS) as genetic risk factors for AD (Jean-Charles et al., 2009; McGuinness et al., 2009; Hollingworth et al., 2011; Guerreiro et al., 2013; Hickman Suzanne and Joseph, 2014).

Our receptor of interest, the chemokine receptor, is involved in substantial inflammatory diseases of the central nervous system (CNS) and functions in the recruitment and immigration of immune cells. These receptors are mainly distributed in microglia and recruited peripheral blood monocytes in the CNS (El, 2010), while they are rarely expressed on neuronal cell membranes 
under normal physiological conditions (Huerta et al., 2004). Increased expression of CCR5 in the CNS is an inflammatory response to many neuropathological diseases, e.g., stroke (Joy et al., 2019), Parkinson's disease (Huerta et al., 2004), multiple sclerosis (SRensen et al., 1999; Trebst et al., 2001), and Rasmussen encephalitis (Bien Christian et al., 2013; Varadkar et al., 2014). At the beginning of this year, an article published in Cell (Joy et al., 2019) further attracted everyone's attention to the association between CCR5 and neuronal plasticity that is potentially relevant to neuroinflammation and $\mathrm{AD}$. In this review, we will elucidate the intricate association between $\mathrm{AD}$, inflammation, and CCR5.

\section{AD AND NEUROINFLAMMATION}

\section{Pathogenesis of AD}

As the most common cause of dementia, $\mathrm{AD}$ is still defined by the combined presence of amyloid and tau; thus, countless studies are conducted with the aim of discerning the enigma of these two pathological factors. However, all current drug clinical trials for amyloid or tau have ended in failure. Researchers are gradually moving away from the simple estimation of linear connection as proposed in the initial amyloid hypothesis (Small and Duff, 2008). Several lines of evidence confirmed that vascular damage increased the risk of later cognitive impairment and finally dementia (Exalto et al., 2013; Gottesman Rebecca et al., 2014; Kuhn et al., 2014; Rawlings Andreea et al., 2014). Additionally, there are considerable disease and lifestyle determinants that could result in increased susceptibility to developing $\mathrm{AD}$, e.g., traumatic brain injury, hypertension, diabetes, obesity, education, exercise, and psychological factors, except for the proverbial aging and risk genetic allele (Norton et al., 2014). Notably, most of these factors are relevant to inflammation and immunity. Consequently, a variety of hypotheses and theories of $\mathrm{AD}$ have been proposed, among which the inflammation hypothesis is receiving growing support (Newcombe et al., 2018; Oliveira et al., 2018; Schultzberg et al., 2018; Spangenberg and Green, 2018). Although the reviews of neuroinflammation and $\mathrm{AD}$ are abundant and comprehensive (for more detail, we recommend Ref; Josef Karkos, 2003; Heppner Frank et al., 2015; Ransohoff, 2016; Cuello, 2017), we will focus on the relationship between microglia and neuroinflammation because microglia harbor the majority of CCR5 in the CNS.

\section{Microglia as a Double-Edged Sword}

Notwithstanding existing evidence indicating that peripheral immune cells can infiltrate brain tissue through the damaged blood-brain barrier (BBB) under pathological conditions and cause inflammation (Villeda Saul et al., 2011), native microglia and activated astrocytes, which widely reside everywhere throughout the brain, are the main contributors to neuroinflammation. Unlike neurons, astrocytes, and oligodendrocytes, microglia are considered resident immune cells from the mesoderm and function in some housekeeping work, including neurogenesis, the trimming and stimulation of synapses, the modulation of cognitive processes, and immunological surveillance. Gradual deterioration of the immune system increases vulnerability to infections and diseases as individuals age. Some altered expression of microgliarelated genes that could accelerate the progression of $\mathrm{AD}$ has been identified in AD patients (Cribbs et al., 2012). Microglia isolated from postmortem aging brains also showed significant transcriptome characteristics compared with those obtained from younger brains; genes associated with celladhesion axon-guided cell surface receptor expression and actin assembly were specifically affected (Galatro et al., 2017). Moreover, microglial cells from the aged cortex show many morphological abnormalities, including the formation of nodal processes and division processes of acellular globules (Streit Wolfgang et al., 2010).

The proteins that microglia produce exhibit dramatic changes during aging, neurodegeneration, and neuroinflammation. For example, secreted cytokines, displayed membrane proteins, and energy and metabolism protein needs differ drastically (Ritzel et al., 2015; Mrdjen et al., 2018). However, the complex relationship between microglia, tau, and amyloid beta protein $(\mathrm{A} \beta)$ remains controversial. On the one hand, many studies have indicated that microglia are capable of congregating around $\mathrm{A} \beta$ and phagocytosing it to attenuate the pathological load. On the other hand, activated microglia could damage neurons and vascular epithelial cells, which lead to additional impairment of cognitive function (Grathwohl and Kalin, 2010; Seabrook et al., 2010; Dagher et al., 2015; Olmos-Alonso et al., 2016; Spangenberg et al., 2016). The distinct subtypes of microglia contribute to the $\mathrm{AD}$ course in a diverse manner, and the heterogeneity of pro- and anti-inflammatory timing of microglia is a formidable obstacle (Martin et al., 2010; Heneka Michael et al., 2013; Medeiros et al., 2013; Chakrabarty et al., 2015; Marie-Victoire et al., 2015; Fu et al., 2016). Reactive microglia can accelerate the propagation of tau pathology, thereby causing a deterioration in inflammation (Yoshiyama et al., 2007; Sanchez-Mejias et al., 2016). Deposition of $\mathrm{A} \beta$ worsens neurodegeneration and triggers pro-inflammatory responses. Moreover, $A \beta$ binds to inflammatory receptors (Yan et al., 1996; Deane et al., 2003; Shirong et al., 2012) and promotes immune-related transcriptional signals (Bonaiuto et al., 1997; Rodrigo et al., 2007) (Figure 1). When microglia and astrocytes clear $A \beta$ through phagocytosis and intracellular degradation, many transmembrane receptors (e.g., LRP-1 and ATP-binding cassette transporter family) bind to $A \beta$, and most of these receptors are essential in immune and inflammatory responses (Anthony et al., 2013; Chuang et al., 2016).

\section{Molecular Receptor Spectrum of Neuroinflammation}

The theoretical framework regarding how inflammation interacts with the development of $\mathrm{AD}$ has been widened and explored on an unprecedented scale. Internationally renowned pharmaceutical companies have already started multiple clinical drug trials on the anti-inflammatory treatment of $\mathrm{AD}$ (Cuello, 2017). Despite cellular components (e.g., microglia, astrocytes, and endothelial cells), an increasing number of receptors, membrane proteins and metabolic enzymes have become candidates for further research and clinical trials. For example, 


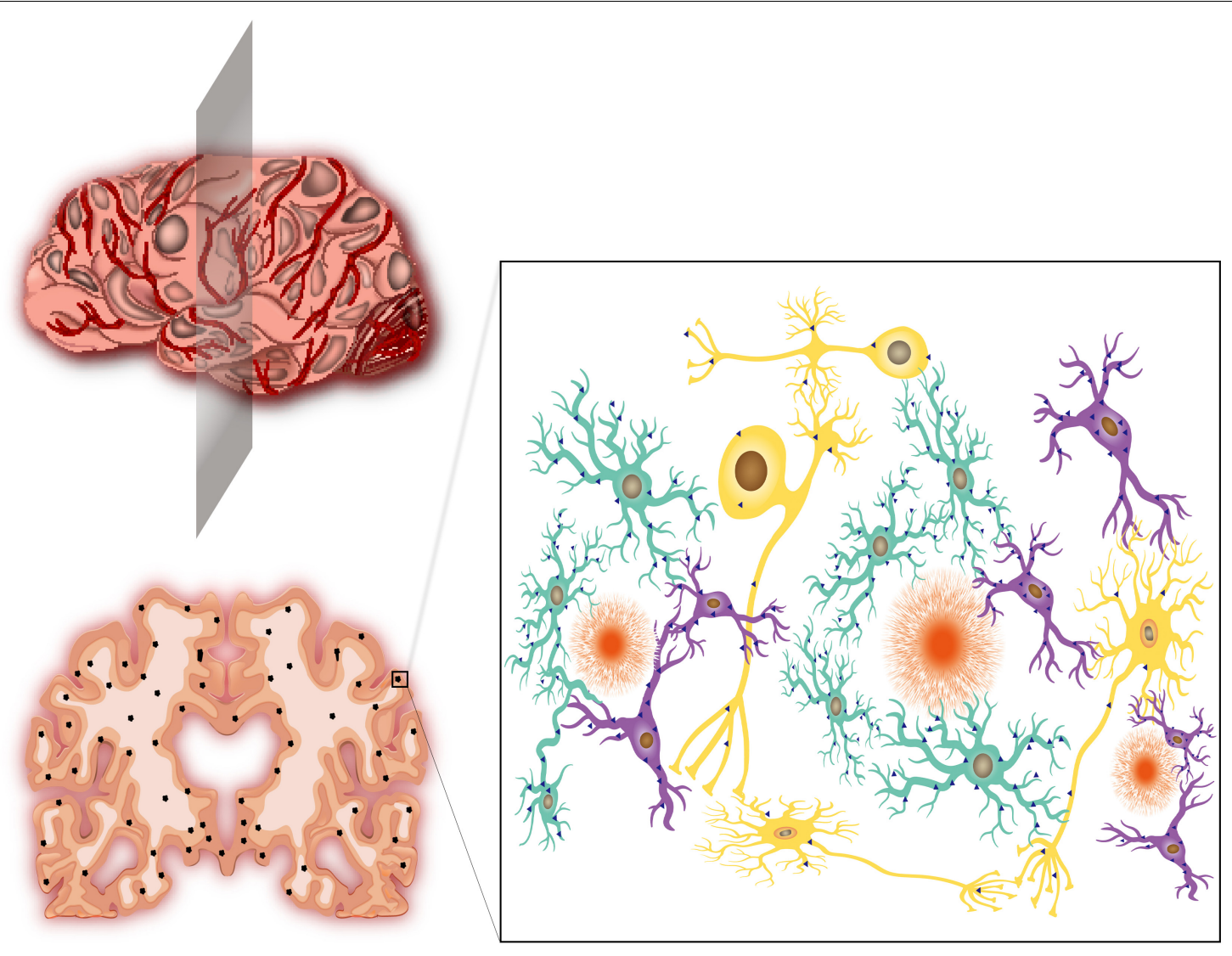

FIGURE 1 | Alzheimer's disease, neuroinflammation and CCR5. (Upper left) The schematic graph of an AD patient's brain. The brain shows varying degrees of shrinkage and vascular inflammation. The gray patches represent neuroinflammation in different regions of $A D$ brain insults. (Lower left) Brain slice of a severe AD patient from the location of shaded plane in the (Upper left) graph. Apparent shrinkage and numerous $A \beta$ depositions are presented. The black dots represent $A \beta$ deposits. (Right) The magnified version of the box in the lower left graph. The A $\beta$ deposits are surrounded by activated astrocytes (agate green) and microglia (purple). The neurons (yellow) are inevitably affected by these neighbors, which leads to disorders of electrical and chemical signal conduction. The blue triangles represent the expression of CCR5. Activated astrocytes and microglia produce abundant CCR5, while neurons express few of them. The radial orange circles are A $\beta$ deposits.

positive modulation of a7 nicotinic acetylcholine receptors (a7nAChRs) had therapeutic potential for its anti-inflammatory effects (Echeverria et al., 2016). The lower dose of colonystimulating factor 1 receptor (CSF1R) inhibitors led to increased hippocampal-dependent spatial memory (Spangenberg and Green, 2017). Angiotensin II receptor blockers (ARBs) were considered a neuroprotective candidate against early damage factors to neurons, astrocytes, microglia, cerebrovascular endothelial, and BBB; consequently, ARBs prevent cognitive loss and dementia (Saavedra, 2016). Mimetics of glucagon-like peptide 1 (GLP-1) receptor agonists, first designed to treat diabetes, were capable of reducing inflammation, oxidative stress, and apoptotic signaling and protecting memory formation (Hölscher, 2018). In addition to membrane receptors, a substantial number of studies revealed that nuclear receptors could be potential interventional targets to suspend dementia progression in $\mathrm{AD}$ (Moutinho and Landreth, 2017). Notably, numerous studies have focused on various inflammatory receptors and diverse signaling pathways. Among these components, chemokine receptors, which are mainly studied in immunology, deserve further attention. The birth of Chinese gene edited infants has greatly enriched scientific theories because some studies showed that CCR5 deficiency could improve both prognosis and neuronal plasticity after stroke and traumatic injury, which encouraged an unprecedented CCR5 research boom (Joy et al., 2019).

\section{CCR5}

\section{CCR5: Structure, Distribution, and Function}

CCR5 belongs to the seven transmembrane G-protein coupled receptors (GPCRs) that transmit signals via heterotrimeric G proteins (Pierce Kristen et al., 2002). CCR5 consists of 7 hydrophobic transmembrane domains with an extracellular $\mathrm{N}$-terminus and cytoplasmic $\mathrm{C}$-terminus, ranging in length from 340 to 370 amino acids (Oppermann, 2004). CCR5 is the receptor for nearly 10 chemotactic proteins of the $\beta$ chemokine family, which are also named CC chemokines (Griffith et al., 2014). 
In humans, the gene encoding the CCR5 protein is situated in the short (p) arm at position 21 on chromosome 3 .

In the immune system, CCR5 widely resides on the surface of antigen-presenting cells (e.g., macrophages, dendritic cells), effector lymphocytes and regulatory T cells (Griffith et al., 2014). The corresponding ligands are presented on effector $\mathrm{T}$ cells and natural killer cells (Nieto et al., 1998; Luther and Cyster, 2001; Hogaboam and Kunkel, 2002). CCR5 regulates chemotaxis and cell activation through interactions with MIP-1 $\alpha$ (CCL3), MIP$1 \beta$ (CCL4), RANTES (CCL5), MCP-2 (CCL8), CCL11 (eotaxin), HCC-1 (CCL14a), and HCC-4 (CCL16) (Alexander et al., 2007).

CCR5 is widely known because it provides access for HIV1 to invade host immune cells. The gp120 envelope protein is a chemokine mimic; thus, it can bind to CCR5 during HIV infection (Murphy, 2001). Additionally, CCR5 can accelerate the transmission of the R5-strain of the HIV-1 virus (LiebermanBlum et al., 2008). CCR $\Delta 32$ is a 32-base-pair deletion that inserts a premature stop codon into the CCR5 receptor locus, leading to receptor dysfunction. Homozygous carriers of this mutation cannot be infected with M-tropics strains of HIV-1 (De and Stumpf, 2004; Gero et al., 2009; Rieger et al., 2010; Kay and Walker, 2014).

Several lines of cancer cells (e.g., breast and prostate cancer cells), instead of normal epithelial cells, express a high level of CCR5, which help the cancer transformation process (VelascoVelázquez et al., 2012; Daniela et al., 2014). Furthermore, the chemotherapy resistance of cancer stem cells could be partly accredited to the expression of CCR5 (Jiao et al., 2018).

In the CNS, these receptors are produced by microglia, astrocytes, and endothelial cells (normally undetectable on neurons) (Shukaliak and Dorovini-Zis, 2000; Mi et al., 2009; Subileau et al., 2009). All existing evidence suggests that CCR5 participates in neuroinflammation and neuroimmunology, including microglial activation (Cowell et al., 2006; Bokhari et al., 2009), microglial chemotaxis (Babcock Alicia et al., 2003; Kyung et al., 2010), monocyte/macrophage chemotaxis (Glass William and Lane Thomas, 2003), lymphocyte chemotaxis (Elodie et al., 2003; Glass William and Lane Thomas, 2003), brain development and cell differentiation (Bakhiet et al., 2001; Khan et al., 2003; Mi et al., 2009; Kyung et al., 2010), neuronal transmission (Adler et al., 2005; Chen et al., 2007; Veronica et al., 2008) and anti-microorganism functions (Mishra Saroj and Lothar, 2009; Haworth et al., 2017; Brelot and Chakrabarti, 2018). Under the same conditions, neuronal death was more notable in the brains of CCR5-/- mice than in those of CCR5+/+ mice (Hee et al., 2009). Knockout of the CCR5 gene was associated with the inadequate development and maturation of dopaminergic neurons (Choi et al., 2013).

\section{CCR5: Signal Pathway}

CCR5 activates the cellular signaling pathway through G proteins, pertussis-sensitive heterotrimeric $G$ proteins and $G$ protein-independent pathways (Oppermann, 2004). The binding of a chemokine ligand to CCR5 results in conformational changes in $G$ proteins, which will enable various signaling cascades, including those of the phosphoinositide-3 kinase (PI3K), protein kinase $\mathrm{C}(\mathrm{PKC})$, and mitogen-activated protein kinases (MAPK), as well as calcium influx (Oppermann, 2004; Sudarshan et al., 2013). At present, G-protein-independent signaling pathways involving the Janus kinases (JAK), pyk2 kinase, and arrestin pathways have been identified (Corno et al., 2001; Mueller and Strange, 2004). These cascades activate various cellular functions, cytoskeleton recombination, and chemotaxis. Calcium flux is an essential procedure for sequent signal activation in the CNS. Given that various types of cells express CCR5, it is not impossible that its diverse biological effects require more than G-proteininitiated pathways. The different chemokine ligands that CCR5 binds to determine distinct signaling pathways accounting for the pleiotropic effects of chemokine signaling (Mueller et al., 2006; Jenny et al., 2015).

Additionally, blockage of CCR5 signaling could not only lead to rejection of HIV but also elicit neuroprotective mechanisms and promote neuron survival, which will alleviate HIV-associated dementia (Kaul and Lipton, 2006; Christoph and Pett Sarah, 2012; Martin-Blondel et al., 2016).

\section{The Efficacy of CCR5 Antagonists}

The promising development of CCR5 receptor inhibitors is largely based on CCR5's identity as a necessary pathway for AIDS infection. The only first-generation CCR5 antagonist that the Food and Drug Administration (FDA) approved, Maraviroc, was well tolerated and showed excellent repression of viral load in patients whose highly active antiretroviral therapy (HAART) failed but not in treatment-naïve patients(Lieberman-Blum et al., 2008; Sierra-Madero et al., 2010; Van Lelyveld et al., 2012). The high efficacy of maraviroc has set the tone for second-generation CCR5 antagonists, which account for the failures of aplaviroc and vicriviroc in clinical trials (Gulick et al., 2007; Leeson and Springthorpe, 2007; Stupple et al., 2011). Various modified and innovative second-generation CCR5 antagonists [e.g., piperidine amide compounds (Imamura et al., 2006; Ernst et al., 2008; Stupple et al., 2011), piperazines and diketopiperazines (Liu et al., 2008)] demonstrated guaranteed efficacy in I/II clinical trials, especially the dual CCR5/CCR2 antagonists (Meyer et al., 2013).

However, more data have revealed that CCR5 antagonists function in other disease courses. Dual CCR5/CCR2 antagonists and cenicriviroc could inhibit the progression of non-alcoholic fatty liver disease (Tacke, 2018; Ogawa et al., 2019). In addition, cenicriviroc could reduce liver injury in cholestatic rodents ( $Y u$ et al., 2018). Moreover, the inhibition of lymphocyte migration caused by CCR5 blockade could alleviate graft-versus-host disease (Reshef et al., 2019). Could the CCR5 blockade provide relief from $\mathrm{AD}$ ?

\section{AD AND CCR5}

The definite relationship between AD and CCR5 remains an open debate. Disputable results from basic experimental studies have diverged into two opposed groups. Most of studies demonstrated that the expression of CCR5 contributes to the development of AD (Table 1), while the minority demonstrated that CCR5 could improve memory function in AD (Table 2). However, all existing epidemiologic studies confirmed that there was no 
TABLE 1 | Studies that CCR5 expression exacerbated AD.

Discovery

Title

Author

Model Methods

Direct evidence Microglia with CCR5 expression are associated with Immunohistochemical study of the $\beta$-chemokine deposition of $A \beta$. receptors CCR3 and CCR5 and their ligands in normal and Alzheimer's disease brains.

CCR5-/ - mice had less activation of microglia and Role of the macrophage inflammatory proteinastrocytes after injection of $\mathrm{A} B$ into lateral ventricle. 1alpha/CC chemokine receptor 5 signaling

pathway in the neuroinflammatory response and cognitive deficits induced by beta-amyloid peptide.

CCR5 antagonists attenuated the neuroinflammation Morphine induces the release of CCL5 from of sub cutaneous administration of lipopolysaccharide astrocytes: potential neuroprotective mechanism by decreasing the number of activated microglia and against the HIV protein gp120.

astrocytes.

CCR5 participated in the impairment of learning and Peripheral T cells overexpress MIP-1 $\alpha$ to enhance memory in AD by activating microglia and promoting its transendothelial migration in Alzheimer's T cells transendothelial migration. disease.

The ligands of CCR5, CCL3 and CCL4, were upregulated in microglia isolated from AD patients' brain and stimulated with $A \beta$.

The CCR5 expression of PBMC from AD patients was significantly higher and in vitro PBMC culture with $A \beta$ increased the $C C R 5$ expression.

The proportion of cells expressing CCR5 (Th1 cells and dendritic cells) was greater in AD patients.

Leukocytes of Patients with Alzheimer's Disease.

$A \beta$ could increase CCR5 expression through cellular Mechanism of amyloid peptide induced CCR5 signaling of c-Raf, ERK-1/ERK-2, and c-Jun $\mathrm{NH} 2$-terminal kinase in PBMC.

expression in monocytes and its inhibition by siRNA for Egr-1.

The curcumin inhibited $A \beta$ associated expression of Curcumin, the active constituent of turmeric, CCR5 by preventing Egr-1 DNA binding to the promoter of CCR5. inhibits amyloid peptide-induced cytochemokine gene expression and CCR5-mediated chemotaxis of THP-1 monocytes by modulating early growth response1 transcription factor.

The CCR5 antagonist (DAPTA) of monocyte chemotaxis, was proved to reduce chronic neuroinflammation of $\mathrm{AD}$.

Update on D-Ala-Peptide T-Amide (DAPTA): A Viral Entry Inhibitor that Blocks CCR5 Chemokine Receptors; Chemokine receptor 5 antagonist D-Ala-peptide T-amide reduces microglia and astrocyte activation within the hippocampus in a neuroinflammatory rat model of Alzheimer's disease.

Indirect evidence Both knockout of CCR5 gene and administration of maraviroc helped new formation of neuronal Is a Therapeutic Target for connections.

Weakening the function of CCR5 in mouse led to enhanced LTP and hippocampus-dependent Stroke and Traumatic Brain Injury.

CCR5 is a suppressor for cortical plasticity and hippocampal learning and memory.

Xia et al., 1998

Passos et al., 2009 Mice Knockout of mice CCR5 gene.

Avdoshina et al., 2010 Rats

Administration of CCR5 antagonist to rats preinjected with lipopolysaccharide.

Man et al., 2007

Human CCR5 detection of peripheral blood mononuclear

and rats cells from AD patients and healthy controls; Periphera intravenous injection of $A \beta$ in rats, followed by administration of CCR5 CCR5 antagonist (2D7 mAb)

Walker et al., 2001 Human Gene array technology.

Reale et al., 2008 Human CCR5 detection of PBMC from AD patients and healthy controls.

Goldeck et al., 2013 Human

Giri et al., 2005

Giri et al., 2005

Human

BMC from AD patients and healthy controls.

CCR5 detection of PBMC from AD patients and healthy controls and in vitro administration of siRNA for inhibiting CCR5 relevant signal pathways.

Human Administration of curcumin into PBMC culture in vitro.

\section{Rosi et at 2005 - Rats - Administration of DAPTA to AD rats:} maraviroc.

Cai et al., $2016 \quad$ Mice Knockout of CCR5 gene. memory. 
TABLE 2 | Studies that CCR5 expression improved AD.

\begin{tabular}{|c|c|c|c|c|}
\hline Discovery & Title & Author & Model & Methods \\
\hline $\begin{array}{l}\text { CCR5-/- mice showed higher A } \beta \text { deposit and } \\
\text { impaired long-term and spatial memory. }\end{array}$ & $\begin{array}{l}\text { CCR5 deficiency induces astrocyte } \\
\text { activation, Abeta deposit and impaired } \\
\text { memory function. }\end{array}$ & Yong et al., 2009 & Mice & Knockout of mice CCR5 gene. \\
\hline $\begin{array}{l}\text { CCR5 expression reduced in amyloid precursor } \\
\text { protein plus presenilin-1 (APP/PS1) mice. }\end{array}$ & $\begin{array}{l}\text { Changes in Chemokines and } \\
\text { Chemokine Receptors Expression in a } \\
\text { Mouse Model of Alzheimer's Disease. }\end{array}$ & Obrador et al., 2019 & Mice & $\begin{array}{l}\text { Detection of CCR5 in APP/PS1 } \\
\text { mice by quantitative RT-PCR and } \\
\text { Western-blot techniques. }\end{array}$ \\
\hline $\begin{array}{l}\text { CCR5 reduction resulted in an increase of } A \beta \\
\text { deposits and impairment of memory. }\end{array}$ & $\begin{array}{l}\text { CCR5 deficiency accelerates } \\
\text { lipopolysaccharide-induced } \\
\text { astrogliosis, amyloid-beta deposit and } \\
\text { impaired memory function. }\end{array}$ & Hwang et al., 2016 & Mice & Knockout of CCR5 gene in mice. \\
\hline $\begin{array}{l}\text { CCR5 gene expression was significantly } \\
\text { reduced over time in Tau-P201L mice. }\end{array}$ & $\begin{array}{l}\text { CXCR4 involvement in } \\
\text { neurodegenerative diseases. }\end{array}$ & Andreassen et al., 2018 & Mice & Tau transgenic mouse models. \\
\hline CCR5-/- mice showed higher A $\beta$ deposition. & $\begin{array}{l}\text { CCR5 deficiency induces astrocyte } \\
\text { activation, } A \beta \text { deposit and impaired } \\
\text { memory function. }\end{array}$ & Yong et al., 2009 & Mice & Knockout of CCR5 gene in mice. \\
\hline
\end{tabular}

association between the CCR5 $\Delta 32$ allele and $\mathrm{AD}$ risk. Therefore, the entanglement of $\mathrm{AD}$ and CCR5 urgently needs to be addressed (Table 3).

\section{The Major Group: CCR5 Exacerbates AD (Table 1)}

Memory, learning and plasticity processes in hippocampal and cortical circuits involve electrochemical activity of neurons, including long-term potentiation (LTP), release of glutamate, activation of $N$-Methyl-D-aspartic acid (NMDA) receptors and $\alpha$-amino-3-hydroxy-5-methyl-4-isoxazolepropionic acid (AMPA) receptors, and the generation of new dendritic spines and axons. Cai et al. (2016) reported that weakening the function of CCR5 in the mouse barrel cortex improved MAPK/CREB signaling, which resulted in enhanced spike-timing-dependent plasticity and experience-dependent plasticity (Figure 2). Consequently, LTP and hippocampus-dependent memory significantly improved, while neuronal CCR5 overaction led to memory deficits (Cai et al., 2016). This cornerstone study underlies the foundation of the relationship between memory and CCR5, which also implies a potential discoverable link between CCR5 and AD. The increase in both CCR5 and CCR3 on some reactive microglia was found in $\mathrm{AD}$ patients and associated with amyloid deposition (Xia et al., 1998). After the administration of $A \beta$ into the lateral ventricle of CCR5-/mice, the activation of microglia and astrocytes was decreased compared with that in CCR5 wild-type mice (Passos et al., 2009). CCR5-/- mice showed decreased astrocytosis and microgliosis in the hippocampus after $A \beta$ injection, which resulted from decreased expression of cyclooxygenase- 2 and inducible nitric oxide (NO) synthase, as well as reduced activation of nuclear factor- $\kappa \mathrm{B}(\mathrm{NF}-\kappa \mathrm{B})$, activator protein-1 and cyclic AMP response element-binding protein (Passos et al., 2009). In humans, there were more widespread reactive astrocytes with CCR5 expression in AD than in healthy (Xia et al., 1998) controls. In addition, the impairment of memory and synaptic dysfunction caused by $\mathrm{A} \beta$ were alleviated in CCR5-/- mice (Passos et al., 2009). Similarly, both knockout of the CCR5 gene and administration of maraviroc (FDA-approved anti-HIV drug) could heighten plasticity in the premotor cortex proximal to the stroke site and upregulate CREB and DLK signaling in neurons, which finally aided in the formation of new connections in the contralateral premotor cortex (Joy et al., 2019). Although this conspicuous study did not connect CCR5 with AD, it suggested that CCR5 and its signaling pathways had a pivotal impact on the generation and regeneration of dendritic spines and synapses. Peripheral blood immune cells can filter into the CNS with the help of

TABLE 3 | Studies that show no association between CCR5 expression and AD development.

\begin{tabular}{|c|c|c|c|c|}
\hline Discovery & Title & Author & Model & Methods \\
\hline $\begin{array}{l}\text { The CCR } 5 \Delta 32 \text { gene mutation in Spanish is not } \\
\text { associated with the AD risk. }\end{array}$ & $\begin{array}{l}\text { The chemokine receptor CCR5-Delta32 gene mutation } \\
\text { is not protective against Alzheimer's disease. }\end{array}$ & Onofre et al., 2004 & Human & Epidemiologic study. \\
\hline $\begin{array}{l}\text { The CCR } 5 \Delta 32 \text { allele did not did not contribute } \\
\text { to the risk of } A D \text {. }\end{array}$ & $\begin{array}{l}\text { Chemokines (RANTES and MCP-1) and chemokine- } \\
\text { receptors (CCR2 and CCR5) gene polymorphisms in } \\
\text { Alzheimer's and Parkinson's disease. }\end{array}$ & Huerta et al., 2004 & Human & Epidemiologic study. \\
\hline $\begin{array}{l}\text { No significant difference was shown in the } \\
\text { distribution of CCR5 between AD patients and } \\
\text { healthy controls in Iran. }\end{array}$ & $\begin{array}{l}\text { Ccr2-64i and Ccr5 } \Delta 32 \text { Polymorphisms in Patients with } \\
\text { Late-Onset Alzheimer's disease; A Study from Iran } \\
\text { (Ccr2-64i And Ccr5 } \Delta 32 \text { Polymorphisms in Alzheimer's } \\
\text { disease). }\end{array}$ & Khorshid et al., 2012 & Human & Epidemiologic study. \\
\hline $\begin{array}{l}\text { No significant differences was demonstrated in } \\
\text { genotype distribution and CCR } 5 \Delta 32 \text { allelic } \\
\text { frequency both in women and in men in Italy. }\end{array}$ & $\begin{array}{l}\text { Association between the Polymorphism of CCR5 and } \\
\text { Alzheimer's Disease: Results of a Study Performed on } \\
\text { Male and Female Patients from Northern Italy. }\end{array}$ & Balistreri et al., 2006 & Human & Epidemiologic study. \\
\hline
\end{tabular}




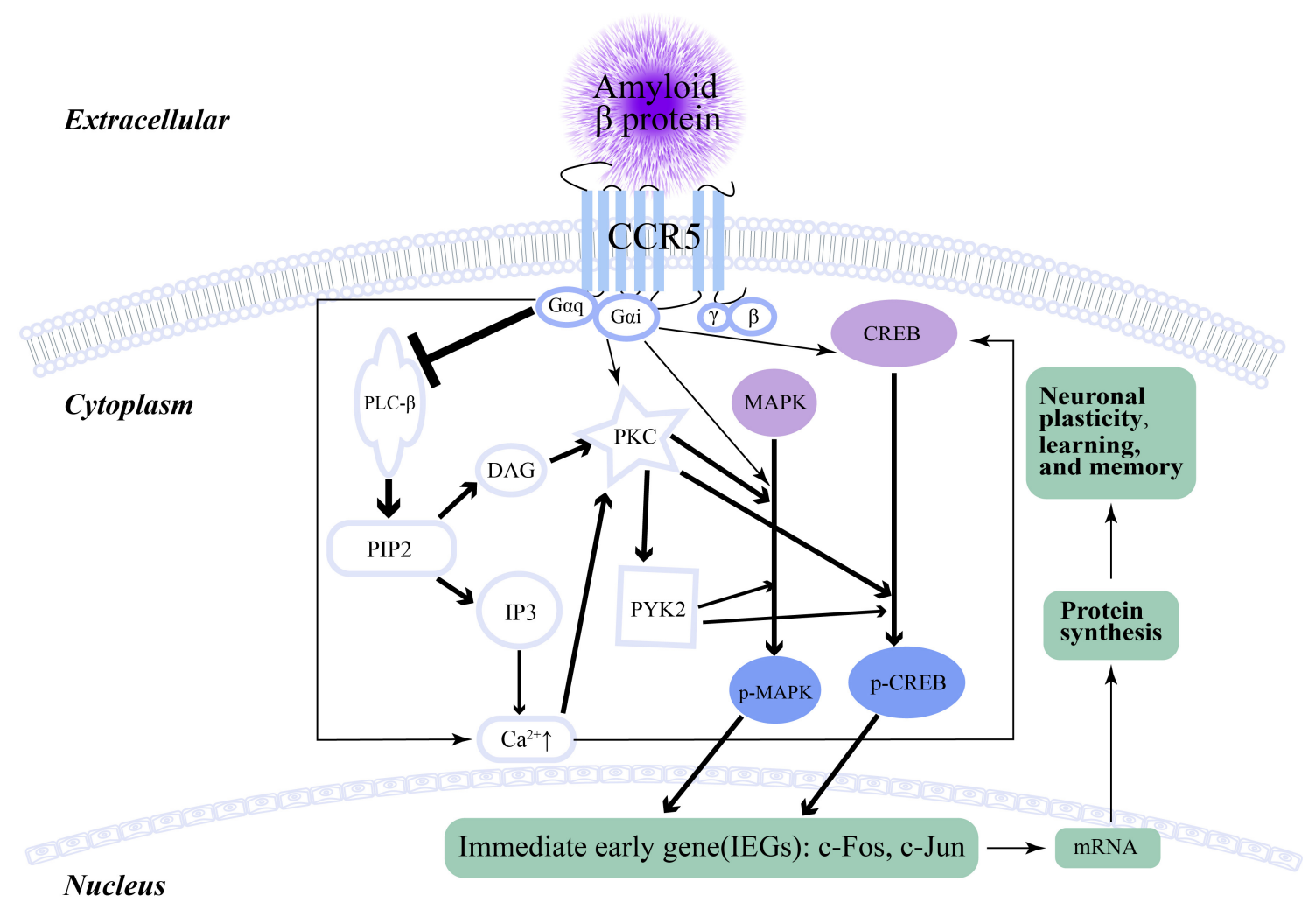

FIGURE 2 | The signaling pathway of CCR5 and neuronal plasticity. The arrow represents promotion, while the $\perp$ represents inhibition. The thickness of the arrow and $\perp$ indicates the intensity of promotion or inhibition.

CCR5 (Man et al., 2007). Man et al. (2007) suggested that CCR5 participated in the impairment of learning and memory in $\mathrm{AD}$ by activating microglia and promoting $\mathrm{T}$ cell transendothelial migration through the Rho/ROCH pathway. CCL3 and CCL4, as ligands for CCR5, were upregulated in microglia isolated from $\mathrm{AD}$ patient brains and stimulated with $\mathrm{A} \beta$ (Walker et al., 2001). In addition, peripheral blood mononuclear cell (PBMC) analysis suggested that the expression of both CCR5 and CCR2 were augmented in $\mathrm{AD}$ patients compared with those in control subjects (Reale et al., 2008). Further experiments suggested that acetylcholinesterase inhibitor (ACEI) was capable of decreasing the expression of CCR 5 and CCR 2 in the PBMCs of AD patients, while in vitro administration of $\mathrm{A} \beta$ increased their expression in PBMCs (Reale et al., 2008). Similar results were also obtained by Goldeck et al. (2013), who found that the distribution of cells expressing CCR4 (expressed on Th2 cells) and CCR5 (Th1 cells and dendritic cells) was also greater in patients and was more distinguished on CD4+ than CD8+ T cells. A CCR5 antagonist could reduce the number of active astrocytes and microglia after lipopolysaccharide injection, which implied that CCR5 was involved in neuroinflammation related to $\mathrm{AD}$ (Combarros et al., 2004). Giri et al. (2005) indicated that A $\beta$ could increase CCR5 expression through cellular signaling of c-Raf, ERK-1/ERK-2, and c-Jun NH2-terminal kinase in PBMCs. As mentioned above, CCR5 is involved in neuroinflammation, wherein various CCR5 antagonists can attenuate the neuroinflammation associated with AD. D-Ala-peptide T-amide (DAPTA), a kind of CCR5 antagonist of monocyte chemotaxis, was shown to reduce chronic neuroinflammation by blocking the release of the proinflammatory cytokines TNF- $\alpha$ and IL-1 (Ruff et al., 2003; Rosi et al., 2005). After the administration of Egr-1 siRNA, A $\beta$-associated CCR5 expression and its concomitant ligands decreased significantly (Giri et al., 2005). Curcumin also inhibited the $A \beta$-associated expression of CCR 5 by preventing Egr-1 DNA binding to the promoter of CCR5 (Giri et al., 2010).

\section{The Minor Group: CCR5 Improves AD (Table 2)}

However, CCR5 expression was reduced, and both chemokine CCL3 and CCL4 chemokine expression levels were augmented in amyloid precursor protein plus presenilin-1 (APP/PS1) mice, which are a common model for AD studies (Obrador et al., 2019). Additionally, Hwang et al. (2016) showed that CCR5 reduction led to higher $A \beta$ deposition and impairment of memory. Lipopolysaccharide injection of CCR5 knockout mice significantly increased astrogliosis and $\mathrm{A} \beta$ deposition compared with those in CCR5 wild-type mice (Hwang et al., 2016). Within the hippocampus and cerebral cortex of Tau-P201L mice, which is another frequently used model for AD, CCR5 gene expression was significantly reduced over time compared with that in wild-type mice, while no distinction was found between other 
brain regions(Andreassen et al., 2018). CCR5-/- mice showed a higher level of $A \beta$, which was related to astrocyte activation and CCR2 overexpression. These changes finally caused memory impairments (Yong et al., 2009).

\section{No Epidemiological Link Between AD and CCR5 (Table 3)}

Despite the fact that experimental studies were full of controversies and the conclusive relationship between $\mathrm{AD}$ and CCR5 remained unknown, the epidemiological evidence was certain and negative. Several epidemiological studies confirmed that there was no differential distribution of the CCR $\Delta 32$ deletion in $\mathrm{AD}$ patients and controls in Italy (Balistreri et al., 2006). Moreover, no differences were observed by gender stratification, by the presence of the ApoE q4 allele, or by the age at onset in genotype distribution and allelic frequency (Balistreri et al., 2006). Identical results were found in Spanish and Iran: the CCR5 $\triangle 32$ allele was not a correlative factor for AD (Galimberti et al., 2004; Onofre et al., 2004; Salvador et al., 2004).

\section{CONCLUSION AND OUTLOOK}

The definite mechanism of $\mathrm{AD}$ remains unclear, but our understanding of $\mathrm{AD}$ has far exceeded the two typical pathological manifestations-A $\beta$ and tau. The neuroinflammation theory of $\mathrm{AD}$ is fascinating an increasing number of researchers. Currently, more than 5000 studies about $\mathrm{AD}$ and neuroinflammation are available on PubMed, and the number is expanding. CCR5 expression was strongly related to microglia and inflammation, which validated an inseparable relationship between inflammation, Alzheimer's disease, and CCR5 (Andreassen et al., 2018). As the most notable receptor among the chemokine receptor family, the accurate function and

\section{REFERENCES}

Adler, M. W., Geller, E. B., Chen, X., and Rogers, T. J. (2005). Viewing chemokines as a third major system of communication in the brain. AAPS J. 7, E865-E870.

Alexander, S. P. H., Mathie, A., and Peters, J. A. (2007). Guide to receptors and channels (GRAC). 3rd Edn. Br. J. Pharmacol. 153(Suppl. 2):S1-S209.

Andreassen, O. A., Höglinger, G., Miller, B. L., Wen, N., Wang, Y., Tan, C., et al. (2018). CXCR4 involvement in neurodegenerative diseases. Transl. Psychiatry 8:73. doi: 10.1038/s41398-017-0049-7

Anthony, F. C., Sanja, A., Stiles Travis, L., Schlobach Ryan, K., Mowen Kerri, A., Gonias Steven, L., et al. (2013). Identification of the low density lipoprotein (LDL) receptor-related protein-1 interactome in central nervous system myelin suggests a role in the clearance of necrotic cell debris. J. Biol. Chem. 288, 4538-4548. doi: 10.1074/jbc.M112.384693

Avdoshina, V., Biggio, F., Palchik, G., Campbell, L. A., and Mocchetti, I. (2010). Morphine induces the release of CCL5 from astrocytes: potential neuroprotective mechanism against the HIV protein gp120. Glia 58, 1630-1639. doi: 10.1002/glia.21035

Babcock Alicia, A., Kuziel William, A., Serge, R., and Trevor, O. (2003). Chemokine expression by glial cells directs leukocytes to sites of axonal injury in the CNS. J. Neurosci. 23, 7922-7930. doi: 10.1523/jneurosci.23-21-07922.2003

Bakhiet, M., Tjernlund, A., Mousa, A., Gad, A., StrMblad, S., Kuziel, W. A., et al. (2001). RANTES promotes growth and survival of human first-trimester forebrain astrocytes. Nat. Cell Biol. 3, 150-157. doi: 10.1038/35055057 subsequent signaling pathways of CCR5 have been well studied. Available epidemiological evidence could provide no connection between the CCR5 $\Delta 32$ gene and AD (Onofre et al., 2004; Salvador et al., 2004; Balistreri et al., 2006). However, given that all of the epidemiological evidence was based on genotype and performed more than a decade ago, potential links may lie deeper than the superficial genotype, such as translational modulation, proteomics, and epigenetics. Despite the controversy, it cannot be denied that CCR5 plays an important role in the process of LTP, cortical plasticity, learning and memory (Cai et al., 2016). We posited that the reason for experimental conflicts between CCR5 and AD are as follows: the animal models and the methods the authors used for acquiring $\mathrm{AD}$ models were varied. Furthermore, compared with administration of small interfering RNA (siRNA), maraviroc and other antagonists, the effect of total knockout of the CCR5 gene could lead to an enormous impact on cellular signal pathways inside the membrane. Further investigation should take these factors into account. Future studies of molecular mechanisms of subsequent intracellular signal pathways caused by CCR5 activation would shed new light on this entanglement between $\mathrm{AD}$ and CCR5.

\section{AUTHOR CONTRIBUTIONS}

TL contributed significantly on this review. JZ reviewed and proposed valuable modifications.

\section{FUNDING}

This work was supported by grants (2018YFA0107900, 31771491, and 2019CXJQ01) from Ministry of Science and Technology of China, the National Nature Science Foundation, and Shanghai Municipal Government.

Balistreri, C. R., Grimaldi, M. P., Vasto, S., Listi, F., Chiappelli, M., Licastro, F., et al. (2006). Association between the polymorphism of CCR5 and Alzheimer's disease: results of a study performed on male and female patients from northern Italy. Ann. N. Y. Acad. Sci. U.S.A. 1089, 454-461. doi: 10.1196/annals. 1386.012

Bien Christian, G., Henning, T., Robert, S., Stefan, K., Horst, U., Marec, V. L., et al. (2013). Rasmussen encephalitis: incidence and course under randomized therapy with tacrolimus or intravenous immunoglobulins. Epilepsia 54, 543-550. doi: 10.1111/epi.12042

Bokhari, S. M., Yao, H., Bethel-Brown, C., Peng, F., Williams, R., Dhillon, N. K., et al. (2009). Morphine enhances Tat-induced activation in murine microglia. J. Neurovirol. 15, 219-228. doi: 10.1080/13550280902913628

Bonaiuto, C., McDonald, P. P., Rossi, F., and Cassatella, M. A. (1997). Activation of nuclear factor-kappa B by beta-amyloid peptides and interferon-gamma in murine microglia. J. Neuroimmunol. 77, 51-56. doi: 10.1016/S0165-5728(97) 00054-4

Brelot, A., and Chakrabarti, L. A. (2018). CCR5 revisited: how mechanisms of HIV entry govern AIDS pathogenesis. J. Mol. Biol. 430, 2557-2589. doi: 10.1016/j. jmb.2018.06.027

Cai, D. J., Huang, S., Lee, Y.-S., Zhou, M., Greenhill, S., Wu, S., et al. (2016). CCR5 is a suppressor for cortical plasticity and hippocampal learning and memory. Elife 5, 1-30. doi: 10.7554/elife.20985

Chakrabarty, P., Li, A., Ceballos-Diaz, C., Eddy, J. A., Funk, C. C., and Moore, B. (2015). IL-10 alters immunoproteostasis in APP mice, increasing plaque burden 
and worsening cognitive behavior. Neuron 85, 519-533. doi: 10.1016/j.neuron. 2014.11.020

Chen, X., Geller, E. B., Rogers, T. J., and Adler, M. W. (2007). Rapid heterologous desensitization of antinociceptive activity between mu or delta opioid receptors and chemokine receptors in rats. Drug Alcohol Depend. 88, 36-41. doi: 10.1016/ j.drugalcdep.2006.09.010

Choi, D. Y., Lee, M. K., and Jin, T. H. (2013). Lack of CCR5 modifies glial phenotypes and population of the nigral dopaminergic neurons, but not MPTP-induced dopaminergic neurodegeneration. Neurobiol. Dis. 49, 159-168. doi: $10.1016 /$ j.nbd.2012.08.001

Christoph, B., and Pett Sarah, L. (2012). Clinical studies with chemokine receptor5 (CCR5)-inhibitors. Curr. Opin. HIV AIDS 7, 456-462. doi: 10.1097/COH. 0b013e328356e933

Chuang, T. Y., Guo, Y., Seki, S. M., Rosen, A. M., Johanson, D. M., and Mandell, J. W. (2016). LRP1 expression in microglia is protective during CNS autoimmunity. Acta Neuropathol Commun. 4:68. doi: 10.1186/s40478-0160343-2

Combarros, O., Infante, J., Llorca, J., Peña, N., Fernández-Viadero, C., and Berciano, J. (2004). The chemokine receptor CCR5- $\Delta 32$ gene mutation is not protective against Alzheimer's disease. Neurosci. Lett. 366, 312-314. doi: 10.1016/j.neulet.2004.05.058

Corno, M. D., Liu, Q. H., Schols, D., Clercq, E. D., Gessani, S., Freedman, B. D., et al. (2001). HIV-1 gp120 and chemokine activation of Pyk2 and mitogen-activated protein kinases in primary macrophages mediated by calcium-dependent, pertussis toxin-insensitive chemokine receptor signaling. Blood 98:2909. doi: 10.1182/blood.v98.10.2909

Cowell, R. M., Xu, H., Parent, J. M., and Silverstein, F. S. (2006). Microglial expression of chemokine receptor CCR5 during rat forebrain development and after perinatal hypoxia-ischemia. J. Neuroimmunol. 173, 155-165. doi: 10.1016/j.jneuroim.2006.01.005

Cribbs, D. H., Berchtold, N. C., Perreau, V., Coleman, P. D., Rogers, J., and Tenner, A. J. (2012). Extensive innate immune gene activation accompanies brain aging, increasing vulnerability to cognitive decline and neurodegeneration: a microarray study. J. Neuroinflammation 9:179. doi: 10.1186/1742-2094-9-179

Cuello, A. C. (2017). Early and late CNS inflammation in Alzheimer's disease: two extremes of a continuum? Trends Pharmacol. Sci. 38, 956-966. doi: 10.1016/j. tips.2017.07.005

Dagher, N. N., Najafi, A. R., Kayala, K. M., Elmore, M. R., White, T. E., and Medeiros, R. (2015). Colony-stimulating factor 1 receptor inhibition prevents microglial plaque association and improves cognition in 3xTg-AD mice. J. Neuroinflammation 12:139. doi: 10.1186/s12974-015-0366-9

Daniela, S., Xuanmao, J., Xiaoming, J., Marco, V. V., Adam, E., Sankar, A., et al. (2014). CCR5 receptor antagonists block metastasis to bone of v-Src oncogenetransformed metastatic prostate cancer cell lines. Cancer Res. 74, 7103-7114. doi: 10.1158/0008-5472.CAN-14-0612

De, S. E., and Stumpf, M. P. (2004). HIV and the CCR5-Delta32 resistance allele. FEMS Microbiol. Lett. 241, 1-12. doi: 10.1016/j.femsle.2004.09.040

Deane, R., Du Yan, S., Submamaryan, R. K., LaRue, B., Jovanovic, S., and Hogg, E. (2003). RAGE mediates amyloid-beta peptide transport across the bloodbrain barrier and accumulation in brain. Nat. Med. 9, 907-913. doi: 10.1038/ nm890

Echeverria, V., Yarkov, A., and Aliev, G. (2016). Positive modulators of the $\alpha 7$ nicotinic receptor against neuroinflammation and cognitive impairment in Alzheimer's disease. Prog. Neurobiol. 144, 142-157. doi: 10.1016/j.pneurobio. 2016.01.002

El, K. J. (2010). Neurodegeneration and the neuroimmune system. Nat. Med. 16:1369. doi: 10.1038/nm1210-1369

Elodie, B., Michéle, K., Jean-Christophe, D., Mireille, V., Matthias, M., Kuziel William, A., et al. (2003). CCR5 deficiency decreases susceptibility to experimental cerebral malaria. Blood 101, 4253-4259. doi: 10.1182/blood2002-05-1493

Ernst, J., Dahl, R., Lum, C., Sebo, L., Urban, J., Miller, S. G., et al. (2008). Anti-HIV1 entry optimization of novel imidazopiperidine-tropane CCR5 antagonists. Bioorg. Med. Chem. Lett. 18, 1498-1501. doi: 10.1016/j.bmcl.2007.12.058

Exalto, L. G., Biessels, G. J., Karter, A. J., Huang, E. S., Katon, W. J., Minkoff, J. R., et al. (2013). Risk score for prediction of 10 year dementia risk in individuals with type 2 diabetes: a cohort study. Lancet Diabetes Endocrinol. 1, 183-190. doi: $10.1016 /$ S2213-8587(13)70048-2
Fu, A. K., Hung, K. W., Yuen, M. Y., Zhou, X., Mak, D. S., and Chan, I. C. (2016). IL-33 ameliorates Alzheimer's disease-like pathology and cognitive decline. Proc. Natl. Acad. Sci. U.S.A. 113, E2705-E2713. doi: 10.1073/pnas.1604032113

Galatro, T. F., Holtman, I. R., Lerario, A. M., Vainchtein, I. D., Brouwer, N., and Sola, P. R. (2017). Transcriptomic analysis of purified human cortical microglia reveals age-associated changes. Nat. Neurosci. 20, 1162-1171. doi: 10.1038/nn. 4597

Galimberti, D., Fenoglio, C., Lovati, C., Gatti, A., Guidi, I., Venturelli, E., et al. (2004). CCR2-64I polymorphism and CCR5Delta32 deletion in patients with Alzheimer's disease. J. Neurol. Sci. 225, 79-83. doi: 10.1016/j.jns.2004.07.005

Gero, H., Daniel, N., Maximilian, M., Susanne, G., Arne, M., Kristina, A., et al. (2009). Long-term control of HIV by CCR5 Delta32/Delta32 stem-cell transplantation. N. Engl. J. Med. 360, 692-698. doi: 10.1056/NEJMoa0802905

Ghalib, A. (2009). The biology of CCR5 and CXCR4. Curr. Opin. HIV AIDS 4, 96-103. doi: 10.1097/COH.0b013e328324bbec

Giri, R. K., Rajagopal, V., and Kalra, V. K. (2010). Curcumin, the active constituent of turmeric, inhibits amyloid peptide-induced cytochemokine gene expression and CCR5-mediated chemotaxis of THP-1 monocytes by modulating early growth response-1 transcription factor. J. Neurochem. 91, 1199-1210. doi: 10.1111/j.1471-4159.2004.02800.x

Giri, R. K., Rajagopal, V., Shahi, S., Zlokovic, B. V., and Kalra, V. K. (2005). Mechanism of amyloid peptide induced CCR5 expression in monocytes and its inhibition by siRNA for Egr-1. Am. J. Physiol. Cell Physiol. 289, C264-C276. doi: 10.1111/j.1471-4159.2004.02800.x

Glass William, G., and Lane Thomas, E. (2003). Functional expression of chemokine receptor CCR5 on CD4(+) T cells during virus-induced central nervous system disease. J. Virol. 77, 191-198. doi: 10.1128/jvi.77.1.191-198. 2003

Goldeck, D., Larbi, A., Pellicanó, M., Alam, I., Zerr, I., Schmidt, C., et al. (2013). Enhanced chemokine receptor expression on leukocytes of patients with Alzheimer's Disease. PLoS One 8:e66664. doi: 10.1371/journal.pone.0066664

Gottesman Rebecca, F., Schneider Andrea, L. C., Marilyn, A., Alvaro, A., Karen, B. R., Laura, C., et al. (2014). Midlife hypertension and 20-year cognitive change: the atherosclerosis risk in communities neurocognitive study. JAMA Neurol. 71, 1218-1227. doi: 10.1001/jamaneurol.2014.1646

Grathwohl, S. A., and Kalin, R. T. (2010). Formation and maintenance of Alzheimer's disease beta-amyloid plaques in the absence of microglia. Nat. Neurosci. 16, 164-167. doi: 10.1038/nn.2432

Griffith, J. W., Sokol, C. L., and Luster, A. D. (2014). Chemokines and chemokine receptors: positioning cells for host defense and immunity. Annu. Rev. Immunol. 32, 659-702. doi: 10.1146/annurev-immunol-032713-5

Guerreiro, R., Wojtas, A., Bras, J., Carrasquillo, M., Rogaeva, E., Majounie, E., et al. (2013). TREM2 variants in Alzheimer's disease. N. Engl. J. Med. 368, 117-127.

Gulick, R., Su, Z., Flexner, C., Hughes, M., Skolnik, P., Wilkin, T., et al. (2007). Phase 2 study of the safety and efficacy of vicriviroc, a CCR5 inhibitor, in HIV1-infected, treatment-experienced patients: AIDS clinical trials group 5211. J. Infect. Dis. 196, 304-312. doi: 10.1086/518797

Haddick, P. C., Larson, J. L., Rathore, N., Bhangale, T. R., Phung, Q. T., Srinivasan, K., et al. (2017). A Common variant of IL-6R is associated with elevated IL-6 pathway activity in Alzheimer's Disease brains. J. Alzheimers Dis. 56, 1037-1054. doi: 10.3233/JAD- 160524

Haworth, K. G., Peterson, C. W., and Kiem, H. P. (2017). CCR5-edited gene therapies for HIV cure: closing the door to viral entry. Cytotherapy 19, 1325-1338. doi: 10.1016/j.jcyt.2017.05.013

Hee, P. M., Kyung, L. Y., Yeon Hee, L., Yun-Bae, K., Young Won, Y., Yoon, N. S., et al. (2009). Chemokines released from astrocytes promote chemokine receptor 5-mediated neuronal cell differentiation. Exp. Cell Res. 315, 2715-2726. doi: 10.1016/j.yexcr.2009.06.017

Heneka, M. T., Carson, M. J., Khoury, J., El Landreth, G. E., Brosseron, F., Feinstein, D. L., et al. (2015). Neuroinflammation in Alzheimer's disease. Lancet Neurol. 14, 388-405. doi: 10.1016/S1474-4422(15)70016-5

Heneka Michael, T., Kummer Markus, P., Andrea, S., Andrea, D., Stephanie, S., Ana, V. S., et al. (2013). NLRP3 is activated in Alzheimer's disease and contributes to pathology in APP/PS1 mice. Nature 493:674. doi: 10.1038/ nature 11729

Heppner Frank, L., Ransohoff Richard, M., and Burkhard, B. (2015). Immune attack: the role of inflammation in Alzheimer disease. Nat. Rev. Neurosci. 16, 358-372. doi: 10.1038/nrn3880 
Hickman Suzanne, E., and Joseph, E. K. (2014). TREM2 and the neuroimmunology of Alzheimer's disease. Biochem. Pharmacol. 88, 495-498. doi: 10.1016/j.bcp. 2013.11.021

Hogaboam, C. M., and Kunkel, S. L. (2002). The role of chemokines in linking innate and adaptive immunity. Curr. Opin. Immunol. 14, 129-135. doi: 10.1016/s0952-7915(01)00308-9

Hollingworth, P., Harold, D., Sims, R., Gerrish, A., Lambert, J. C., Carrasquillo, M. M., et al. (2011). Common variants in ABCA7, MS4A6A/MS4A4E, EPHA1, CD33 and CD2AP are associated with Alzheimer's disease. Nat. Genet. 43, 429-435. doi: 10.1038/ng.803

Hölscher, C. (2018). Novel dual GLP-1/GIP receptor agonists show neuroprotective effects in Alzheimer's and Parkinson's disease models. Neuropharmacology 136, 251-259. doi: 10.1016/j.neuropharm.2018.01.040

Huerta, C., Álvarez, V., Mata, I. F., Coto, E., Ribacoba, R., Martínez, C., et al. (2004), Chemokines (RANTES and MCP-1) and chemokine-receptors (CCR2 and CCR5) gene polymorphisms in Alzheimer's and Parkinson's disease. Neurosci. Lett. 370, 151-154. doi: 10.1016/j.neulet.2004.08.016

Hwang, C. J., Mi, H. P., Hwang, J. Y., Ju, H. K., Na, Y. Y., Sang, Y. O., et al. (2016). CCR5 deficiency accelerates lipopolysaccharide-induced astrogliosis, amyloidbeta deposit and impaired memory function. Oncotarget 7, 11984-11999. doi: 10.18632/oncotarget. 7453

Imamura, S., Ichikawa, T., Nishikawa, Y., Kanzaki, N., Takashima, K., Niwa, S., et al. (2006). Discovery of a piperidine-4-carboxamide CCR5 antagonist (TAK220) with highly potent anti-HIV-1 activity. J. Med. Chem. 49, 2784-2793. doi: $10.1021 / \mathrm{jm} 051034 \mathrm{q}$

Irene, L. G., Agatha, S., Ester, A., Paula, G. E., Belen, A., Franc, L., et al. (2015). Neuroinflammatory signals in Alzheimer disease and APP/PS1 transgenic mice: correlations with plaques, tangles, and oligomeric species. J. Neuropathol. Exp. Neurol. 74, 319-344. doi: 10.1097/NEN.0000000000000176

Jean-Charles, L., Simon, H., Gael, E., Dominique, C., Kristel, S., Mikko, H., et al. (2009). Genome-wide association study identifies variants at CLU and CR1 associated with Alzheimer's disease. Nat. Genet. 41, 1094-1099.

Jenny, C., Céline, G., Alexandre, H., Marc, P., and Jean-Yves, S. (2015). Biased signaling at chemokine receptors. J. Biol. Chem. 290, 9542-9554. doi: 10.1074/ jbc.M114.596098

Jiao, X., Velasco-Velázquez, M. A., Wang, M., Li, Z., Rui, H., Peck, A. R., et al. (2018). CCR5 governs DNA damage repair and breast cancer stem cell expansion. Cancer Res. 78, 1657-1671. doi: 10.1158/0008-5472.CAN-17-5

Josef Karkos, M. D. (2003). Immunotherapeutic approaches to Alzheimer's disease. Science 302, 834-838. doi: 10.1126/science.1088469

Joy, M. T., Ben Assayag, E., Shabashov-Stone, D., Liraz-Zaltsman, S., Mazzitelli, J., Arenas, M., et al. (2019). CCR5 is a therapeutic target for recovery after stroke and traumatic Brain injury. Cell 176, 1143-1157.e13. doi: 10.1016/j.cell.2019. 01.044

Kaul, M., and Lipton, S. A. (2006). Mechanisms of neuronal injury and death in HIV-1 associated dementia. Curr. HIV Res. 4, 307-318. doi: 10.2174/ 157016206777709384

Kay, M. A., and Walker, B. D. (2014). Engineering cellular resistance to HIV. N. Engl. J. Med. 370, 968-969. doi: 10.1056/nejme 1400593

Khan, M. Z., Brandimarti, R., Musser, B. J., Resue, D. M., Fatatis, A., and Meucci, O. (2003). The chemokine receptor CXCR4 regulates cell-cycle proteins in neurons. J. Neurovirol. 9, 300-314. doi: 10.1080/713831547

Khorshid, H. R. K., Manoochehri, M., Nasehi, L., Ohadi, M., Rahgozar, M., and Kamali, K. (2012). CCR2-64i and CCR5 $\Delta 32$ polymorphisms in patients with late-onset Alzheimer's disease; a study from Iran (CCR2-64i and CCr5 $\Delta 32$ polymorphisms in Alzheimer's disease). Iran. J. Basic Med. Sci. 15, 937-944.

Khoury, J. E. (2010). Neurodegeneration and the neuroimmune system. Nat. Med. 16, 1369-1370. doi: 10.1038/nm1210- 1369

Kuhn, H. G., Nyberg, J., Åberg, M. A. I., Nilsson, M., Torén, K., Schiöler, L., et al. (2014). Cardiovascular and cognitive fitness at age 18 and risk of early-onset dementia. Brain 137, 1514-1523. doi: 10.1093/brain/awu041

Kyung, H. Y., Phu, V., Sylvia, F., Block Michelle, L., Hauser Kurt, F., and Knapp Pamela, E. (2010). beta-Chemokine production by neural and glial progenitor cells is enhanced by HIV-1 tat: effects on microglial migration. J. Neurochem. 114, 97-109. doi: 10.1111/j.1471-4159.2010.06744.x

Leeson, P. D., and Springthorpe, B. (2007). The influence of drug-like concepts on decision-making in medicinal chemistry. Nat. Rev. Drug Discov. 6, 881-890. doi: $10.1038 / \mathrm{nrd} 2445$
Lieberman-Blum, S. S. B., Fung, H. B., and Bandres, J. C. (2008). Maraviroc: a CCR5-receptor antagonist for the treatment of HIV-1 infection. Clin. Ther. 30, 1228-1250. doi: 10.1016/s0149-2918(08)80048-3

Liu, Y., Enkun, Z., Kunqian, Y., Jin, Z., Yu, Z., Xin, X., et al. (2008). Discovery of a novel CCR5 antagonist lead compound through fragment assembly. Molecules 13, 2426-2441. doi: 10.3390/molecules 13102426

Luther, S. A., and Cyster, J. G. (2001). Chemokines as regulators of T cell differentiation. Nat. Immunol. 2, 102-107. doi: 10.1038/84205

Man, S. M., Ma, Y. R., Shang, D. S., Zhao, W. D., Bo, L., Guo, D. W., et al. (2007). Peripheral T cells overexpress MIP-1 $\alpha$ to enhance its transendothelial migration in Alzheimer's disease. Neurobiol. Aging 28, 485-496. doi: 10.1016/j. neurobiolaging.2006.02.013

Marie-Victoire, G. S., Doty Kevin, R., David, G., Javier, R., Leung Brian, P., Kavon, R. Z., et al. (2015). Illo deficiency rebalances innate immunity to mitigate Alzheimer-like pathology. Neuron 85, 534-548. doi: 10.1016/j.neuron.2014. 12.068

Martin, F., Tobias, B., Jung Christian, K. E., Steffen, B., Page Richard, M., Gerda, M., et al. (2010). Microglial Cx3cr1 knockout prevents neuron loss in a mouse model of Alzheimer's disease. Nat. Neurosci. 13, 411-413. doi: 10.1038/nn.2511

Martin-Blondel, G., Brassat, D., Bauer, J., Lassmann, H., and Liblau, R. S. (2016). CCR5 blockade for neuroinflammatory diseases - beyond control of HIV. Nat. Rev. Neurol. 12:95. doi: 10.1038/nrneurol.2015.248

McGuinness, B., Schürmann, B., Deloukas, P., Kehoe, P. G., Jones, N., Hardy, J., et al. (2009). Genome-wide association study identifies variants at CLU and PICALM associated with Alzheimer's disease. Nat. Genet. 41, 1088-1093. doi: 10.1038/ng.440

Medeiros, R., Kitazawa, M., Passos, G. F., Baglietto-Vargas, D., Cheng, D., and Cribbs, D. H. (2013). Aspirin-triggered lipoxin A4 stimulates alternative activation of microglia and reduces Alzheimer disease-like pathology in mice. Am. J. Pathol. 182, 1780-1789. doi: 10.1016/j.ajpath.2013.01.051

Meyer, M. D., Wang, X., Guo, T., Wei, R., and Wang, L. J. (2013). Chemokine receptor antagonists. J. Med. Chem. 55, 9363-9392.

Mi, H. P., Yong, K. L., Lee, Y. H., Kim, Y. B., Yun, Y. W., Sang, Y. N., et al. (2009). Chemokines released from astrocytes promote chemokine receptor 5-mediated neuronal cell differentiation. Exp. Cell Res. 315, 2715-2726. doi: 10.1016/j.yexcr. 2009.06.017

Mishra Saroj, K., and Lothar, W. (2009). Advances in the management of cerebral malaria in adults. Curr. Opin. Neurol. 22, 302-307. doi: 10.1097/wco. 0b013e32832a323d

Moutinho, M., and Landreth, G. E. (2017). Therapeutic potential of nuclear receptor agonists in Alzheimer's disease. J. Lipid Res. 58, 1937-1949. doi: 10.1128/MCB.00349-14

Mrdjen, D., Pavlovic, A., Hartmann, F. J., Schreiner, B., Utz, S. G., and Leung, B. P. (2018). High-dimensional single-cell mapping of central nervous system immune cells reveals distinct myeloid subsets in health, aging, and disease. Immunity 48, 380-395.E6. doi: 10.1016/j.immuni.2018.01.011

Mueller, A., Mahmoud, N. G., and Strange, P. G. (2006). Diverse signalling by different chemokines through the chemokine receptor CCR5. Biochem. Pharmacol. 72, 739-748. doi: 10.1016/j.bcp.2006.06.001

Mueller, A., and Strange, P. G. (2004). CCL3, acting via the chemokine receptor CCR5, leads to independent activation of janus kinase 2 (JAK2) and G i proteins. FEBS Lett. 570, 126-132. doi: 10.1016/j.febslet.2004.04.100

Murphy, P. M. (2001). Viral exploitation and subversion of the immune system through chemokine mimicry. Nat. Immunol. 2, 116-122. doi: 10.1038/84214

Newcombe, E. A., Camats-Perna, J., Silva, M. L., Valmas, N., Huat, T. J., and Medeiros, R. (2018). Inflammation: the link between comorbidities, genetics, and Alzheimer's disease. J. Neuroinflammation 15:276. doi: 10.1186/s12974018-1313-13

Nieto, M., Navarro, F., Perez-Villar, J. J., Pozo, M. A. D., González-Amaro, R., Mellado, M., et al. (1998). Roles of chemokines and receptor polarization in NK-target cell interactions. J. Immunol. 161, 3330-3339.

Norton, S., Matthews, F. E., Barnes, D. E., Yaffe, K., and Brayne, C. (2014). Potential for primary prevention of Alzheimer's disease: an analysis of population-based data. Lancet Neurol. 13, 788-794. doi: 10.1016/S1474-4422(14)70136-X

Obrador, E., Mauricio, M. D., Iradi, A., Vila, J. M., Guerra-Ojeda, S., Cauli, O., et al. (2019). Changes in chemokines and chemokine receptors expression in a mouse model of Alzheimer's Disease. Int. J. Biol. Sci. 15, 453-463. doi: 10.7150/ ijbs.26703 
Ogawa, Y., Yoneda, M., Kobayashi, T., Honda, Y., Kessoku, T., Imajo, K., et al. (2019). Present and emerging pharmacotherapies for non-alcoholic steatohepatitis in adults. Expert Opin. Pharmacother. 20, 69-82. doi: 10.1080/ 14656566.2018.1543403

Oliveira, B. C. L., Bellozi, P. M. Q., Reis, H. J., and de Oliveira, A. C. P. (2018). Inflammation as a possible link between dyslipidemia and Alzheimer's Disease. Neuroscience 376, 127-141. doi: 10.1016/j.neuroscience.2018.02.012

Olmos-Alonso, A., Schetters, S. T., Sri, S., Askew, K., Mancuso, R., and VargasCaballero, M. (2016). Pharmacological targeting of CSF1R inhibits microglial proliferation and prevents the progression of Alzheimer's-like pathology. Brain 139, 891-907. doi: 10.1093/brain/awv379

Onofre, C., Jon, I., Javier, L., Nicolás, P., Carlos, F. V., and José, B. (2004). The chemokine receptor CCR5-Delta32 gene mutation is not protective against Alzheimer's disease. Neurosci. Lett. 366, 312-314. doi: 10.1016/j.neulet.2004. 05.058

Oppermann, M. (2004). Chemokine receptor CCR5: insights into structure, function, and regulation. Cell. Signal. 16, 1201-1210. doi: 10.1016/j.cellsig.2004. 04.007

Passos, G. F., Figueiredo, C. P., Rui, D. S. P., Pandolfo, P., Duarte, F. S., Medeiros, R., et al. (2009). Role of the macrophage inflammatory protein-1alpha/CC chemokine receptor 5 signaling pathway in the neuroinflammatory response and cognitive deficits induced by beta-amyloid peptide. Am. J. Pathol. 175, 1586-1597. doi: 10.2353/ajpath.2009.081113

Pierce Kristen, L., Premont Richard, T., and Lefkowitz Robert, J. (2002). Seventransmembrane receptors. Nat. Rev. Mol. Cell Biol. 3, 639-650.

Power, C. A., Meyer, A., Nemeth, K., Bacon, K. B., Hoogewerf, A. J., Proudfoot, A. E., et al. (1995). Molecular cloning and functional expression of a novel CC chemokine receptor cDNA from a human basophilic cell line. J. Biol. Chem. 270, 19495-19500. doi: 10.1074/jbc.270.33.19495

Ransohoff, R. M. (2016). How neuroinflammation contributes to neurodegeneration. Science 353, 777-783. doi: 10.1126/science.aag2590

Rawlings Andreea, M. A., Richey, S., Schneider Andrea, L. C., Josef, C., Marilyn, A., David, C., et al. (2014). Diabetes in midlife and cognitive change over 20 years: a cohort study. Ann. Intern. Med. 161, 785-793. doi: 10.7326/M14-0737

Reale, M., Iarlori, C., Feliciani, C., and Gambi, D. (2008). Peripheral chemokine receptors, their ligands, cytokines and Alzheimer's disease. J. Alzheimers Dis. 14, 147-159. doi: 10.3233/jad-2008-14203

Reshef, R., Ganetsky, A., Acosta, E. P., Blauser, R., Crisalli, L., McGraw, J., et al. (2019). Extended CCR5 blockade for graft-versus-host disease Prophylaxis improves outcomes of reduced intensity unrelated donor hematopoietic cell transplantation: a Phase II clinical trial. Biol. Blood Marrow Transplant 25, 515-521. doi: 10.1016/j.bbmt.2018.09.034

Rieger, K., Loddenkemper, C., Hofmann, J., Thiel, E., Schneider, T., Hutter, G., et al. (2010). Evidence for the cure of HIV infection by CCR5 32/32 stem cell transplantation. Blood 117, 2791-2799. doi: 10.1182/blood-2010-09309591

Ritzel, R. M., Patel, A. R., Pan, S., Crapser, J., Hammond, M., Jellison, E., et al. (2015). Age- and location-related changes in microglial function. Neurobiol. Aging 36, 2153-2163. doi: 10.1016/j.neurobiolaging.2015.02.016

Rodrigo, M., Rui, D. S. P., Passos Giselle, F., Pablo, P., Duarte Filipe, S., Franco Jeferson, L., et al. (2007). Connecting TNF-alpha signaling pathways to iNOS expression in a mouse model of Alzheimer's disease: relevance for the behavioral and synaptic deficits induced by amyloid beta protein. J. Neurosci 27 , 5394-5404. doi: 10.1523/jneurosci.5047-06.2007

Rosi, S., Pert, C. B., Ruff, M. R., Mcganngramling, K., and Wenk, G. L. (2005). Chemokine receptor 5 antagonist D-Ala-peptide T-amide reduces microglia and astrocyte activation within the hippocampus in a neuroinflammatory rat model of Alzheimer's disease. Neuroscience 134, 671-676. doi: 10.1016/j. neuroscience.2005.04.029

Ruff, R., Polianova, M., Yang, Q. E., Leoung, G. S., Ruscetti, F. W., and Pert, C. B. (2003). Update on D-Ala-Peptide T-Amide (DAPTA): a viral entry inhibitor that blocks CCR5 chemokine receptors. Curr. HIV Res. 1, 51-67. doi: 10.2174/ 1570162033352066

Saavedra, J. M. (2016). Evidence to consider angiotensin II receptor blockers for the treatment of early Alzheimer's Disease. Cell. Mol. Neurobiol. 36, 259-279. doi: 10.1007/s10571-015-0327-y

Salvador, C., Huerta, C., Ribacoba, R., Mata, I. F., Coto, E., Martínez, C., et al. (2004). Chemokines (RANTES and MCP-1) and chemokine-receptors (CCR2 and CCR5) gene polymorphisms in Alzheimer's and Parkinson's disease. Neurosci. Lett. 370, 151-154. doi: 10.1016/j.neulet.2004.08.016

Sanchez-Mejias, E., Navarro, V., Jimenez, S., Sanchez-Mico, M., Sanchez-Varo, R., and Nunez-Diaz, C. (2016). Soluble phospho-tau from Alzheimer's disease hippocampus drives microglial degeneration. Acta Neuropathol. 132, 897-916. doi: 10.1007/s00401-016-1630-5

Schultzberg, M., Hjorth, E., Zhu, M., Wang, X., and Sun, L. (2018). Can inflammation be resolved in Alzheimer's disease? Ther. Adv. Neurol. Disord. 11:175628641879110. doi: 10.1177/1756286418791107

Seabrook, T. J., Jiang, L., Maier, M., and Lemere, C. A. (2010). Minocycline affects microglia activation, A $\beta$ deposition, and behavior in APP-tg mice. Glia 53, 776-782. doi: 10.1002/glia.20338

Shirong, L., Yang, L., Wenlin, H., Lisa, W., Kiliaan Amanda, J., Botond, P., et al. (2012). TLR2 is a primary receptor for Alzheimer's amyloid $\beta$ peptide to trigger neuroinflammatory activation. J. Immunol. 188, 1098-1107. doi: 10.4049/ jimmunol.1101121

Shukaliak, J. A., and Dorovini-Zis, K. (2000). Expression of the $\beta$-chemokines RANTES and MIP- $1 \beta$ by human brain microvessel endothelial cells in primary culture. J. Neuropathol. Exp. Neurol. 59, 339-352. doi: 10.1093/jnen/59.5.339

Sierra-Madero, J., Di Perri, G., Wood, R., Saag, M., Frank, I., Craig, C., et al. (2010). Efficacy and safety of maraviroc versus efavirenz, both with zidovudine/lamivudine: 96-week results from the merit study. HIV Clin. Trials 11, 125-132. doi: 10.1310/hct1103-125

Small, S. A., and Duff, K. (2008). Linking A $\beta$ and Tau in late-onset Alzheimer's Disease: a dual pathway hypothesis. Neuron 60, 534-542. doi: 10.1016/j.neuron. 2008.11.007

Spangenberg, E. E., and Green, K. N. (2017). Inflammation in Alzheimer's disease: lessons learned from microglia-depletion models. Brain Behav. Immun. 61, 1-11. doi: 10.1016/j.bbi.2016.07.003

Spangenberg, E. E., and Green, K. N. (2018). Inflammation in Alzheimer's Disease: lessons learned from microglia-depletion models. Brain Behav Immun. 61, 1-11. doi: 10.1016/j.bbi.2016.07.003

Spangenberg, E. E., Lee, R. J., Najafi, A. R., Rice, R. A., Elmore, M. R., and BlurtonJones, M. (2016). Eliminating microglia in Alzheimer's mice prevents neuronal loss without modulating amyloid-beta pathology. Brain 139, 1265-1281. doi: 10.1093/brain/aww016

SRensen, T. L., Tani, M., Jensen, J., Pierce, V., Lucchinetti, C., Folcik, V. A., et al. (1999). Expression of specific chemokines and chemokine receptors in the central nervous system of multiple sclerosis patients. J.Clin.Invest. 103, 807-815. doi: $10.1172 /$ jci5150

Streit Wolfgang, J., Sammons Nicole, W., Kuhns Amanda, J., and Larry, S. (2010). Dystrophic microglia in the aging human brain. Glia 45:208. doi: 10.1002/glia. 10319

Stupple, P. A., Batchelor, D. V., Corless, M., Dorr, P. K., Ellis, D., Fenwick, D. R., et al. (2011). An imidazopiperidine series of CCR5 antagonists for the treatment of HIV: the discovery of $\mathrm{N}-\{(1 \mathrm{~S})$-1-(3-fluorophenyl)-3-[(3- endo)-3(5-isobutyryl-2- methyl-4,5,6,7-tetrahydro-1 H -imidazo[4,5- c]pyridin-1-yl)8-azabicyclo[3.2.1] oct-8-yl]propyl\}acetamide (PF-232798). J. Med. Chem. 54, 67-77. doi: 10.1021/jm100978n

Subileau, E., Rezaie Pdavies, H., Colyer, F., Greenwood, J., Male, D., and Romero, I. (2009). Expression of chemokines and their receptors by human brain endothelium: implications for multiple sclerosis. J. Neuropathol. Exp. Neurol. 68, 227-240. doi: 10.1097/NEN.0b013e318197eca7

Sudarshan, R., Bassoni Daniel, L., Campbell James, J., Gerard Norma, P., Craig, G., and Wehrman Tom, S. (2013). Biased agonism as a mechanism for differential signaling by chemokine receptors. J. Biol. Chem. 288, 35039-35048. doi: 10.1074/jbc.M113.479113

Tacke, F. (2018). Cenicriviroc for the treatment of non-alcoholic steatohepatitis and liver fibrosis. Expert Opin. Investig. Drugs 27, 301-311. doi: 10.1080/13543784. 2018.1442436

Trebst, C., Sørensen, T. L., Kivisäkk, P., Cathcart, M. K., Hesselgesser, J., Horuk, R., et al. (2001). CCR1+/CCR5+ mononuclear phagocytes accumulate in the central nervous system of patients with multiple sclerosis. Am. J. Pathol. 159, 1701-1710. doi: 10.1016/s0002-9440(10)63017-9

Van Lelyveld, S. F. L., Wensing, A. M. J., and Hoepelman, A. I. M. (2012). The MOTIVATE trials: maraviroc therapy in antiretroviral treatment-experienced HIV-1-infected patients. Expert Rev. Anti. Infect. Ther. 10, 1241-1247. doi: $10.1586 /$ eri.12.114 
Varadkar, S., Bien, C. G., Kruse, C. A., Jensen, F. E., Bauer, J., Pardo, C. A., et al. (2014). Rasmussen's encephalitis: clinical features, pathobiology, and treatment advances. Lancet Neurol. 13, 195-205. doi: 10.1016/s1474-4422(13) 70260-6

Velasco-Velázquez, M., Jiao, X., De, L. F. M., Pestell, T. G., Ertel, A., Lisanti, M. P., et al. (2012). CCR5 antagonist blocks metastasis of basal breast cancer cells. Cancer Res. 72:3839. doi: 10.1158/0008-5472.CAN-11-3917

Veronica, M., Fabio, L., Elisa, N., Marco, P., Fotios, K., Paolo, S., et al. (2008). Rantes modulates the release of glutamate in human neocortex. J. Neurosci. 28, 12231-12240. doi: 10.1523/JNEUROSCI.3212-08.2008

Villeda Saul, A., Jian, L., Mosher Kira, I., Bende, Z., Markus, B., Gregor, B., et al. (2011). The ageing systemic milieu negatively regulates neurogenesis and cognitive function. Nature 477, 90-94. doi: 10.1038/nature10357

Vincent, B., Mohammed, F., Martine, L., Jane, R., Gordon, W., and Serge, R. (2009). Powerful beneficial effects of macrophage colony-stimulating factor on betaamyloid deposition and cognitive impairment in Alzheimer's disease. Brain 132, 1078-1092. doi: 10.1093/brain/awn331

Walker, D. G., Lue, L. F., and Beach, T. G. (2001). Gene expression profiling of amyloid beta peptide-stimulated human post-mortem brain microglia. Neurobiol. Aging 22, 957-966. doi: 10.1016/s0197-4580(01)00306-2

Xia, M. Q., Qin, S. X., Wu, L. J., Mackay, C. R., and Hyman, B. T. (1998). Immunohistochemical study of the $\beta$-Chemokine receptors CCR3 and CCR5 and their ligands in normal and Alzheimer's disease brains. Am. J. Pathol. 153, 31-37. doi: 10.1016/s0002-9440(10)65542-3
Yan, S. D., Chen, X., Fu, J., Chen, M., Zhu, H., and Roher, A. (1996). Rage and amyloid-beta peptide neurotoxicity in Alzheimer's disease. Nature 382, 685-691. doi: 10.1038/382685a0

Yong, K. L., Dong, H. K., Oh, K. W., Nam, S. Y., Lee, B. J., Yun, Y. W., et al. (2009). CCR5 deficiency induces astrocyte activation, $A \beta$ deposit and impaired memory function. Neurobiol. Learn. Mem. 92, 356-363. doi: 10.1016/j.nlm.2009.04.003

Yoshiyama, Y., Higuchi, M., Zhang, B., Huang, S. M., Iwata, N., and Saido, T. C. (2007). Synapse loss and microglial activation precede tangles in a P301S tauopathy mouse model. Neuron 53, 337-351. doi: 10.1016/j.neuron.2007. 01.010

Yu, D., Cai, S., Mennone, A., Vig, P., and Boyer, J. L. (2018). Cenicriviroc, a cytokine receptor antagonist, potentiates all-trans retinoic acid in reducing liver injury in cholestatic rodents. Liver Int. 38, 1128-1138. doi: 10.1111/liv.13698

Conflict of Interest Statement: The authors declare that the research was conducted in the absence of any commercial or financial relationships that could be construed as a potential conflict of interest.

Copyright (c) $2019 \mathrm{Li}$ and Zhu. This is an open-access article distributed under the terms of the Creative Commons Attribution License (CC BY). The use, distribution or reproduction in other forums is permitted, provided the original author(s) and the copyright owner(s) are credited and that the original publication in this journal is cited, in accordance with accepted academic practice. No use, distribution or reproduction is permitted which does not comply with these terms. 